\title{
IPTEKS PERENCANAAN LABA KONTRIBUSI PADA USAHA MANUFAKTUR
}

\author{
Novi Swandari Budiarso ${ }^{1}$, Winston Pontoh ${ }^{1}$ \\ ${ }^{1}$ Program Studi Profesi Akuntan, Fakultas Ekonomi dan Bisnis, Universitas Sam Ratulangi, Jl. Kampus Bahu, \\ Manado, 95115, Indonesia
}

\begin{abstract}
The manufacturing firms have implicit and explicit goals and objectives. In order to achieve these goal and objective then manager needs accounting information. The accounting information created and used by management is intended primarily for planning and control decisions. One of the accounting information is cost accounting that can be used as a tool for planning the profit as the objective of the companies. Manufacturing costs are identified as variable costs or fixed costs under cost behavior analysis. Regression analysis is the one of the cost estimation methods in term to estimate the fixed costs and variable costs where the results of estimation are used to calculate the contribution margin.
\end{abstract}

Keywords: contribution margin; total cost; fixed cost; variable cost

\section{PENDAHULUAN}

Secara umum, sebuah perusahaan didirikan dengan tujuan untuk memaksimumkan nilai dari pemilik perusahaan atau pemegang saham (Ross et al., 2017:11; Jensen dan Meckling, 1976; Ozuomba et al., 2016). Guna mencapai tujuan ini, maka sebuah perusahaan akan menghadapi persaingan dalam menjalani siklus hidupnya (Lorenzon et al., 2018; Weerawardena dan O'Cass, 2004). Dampak adanya persaingan menyebabkan perusahaan menciptakan strategi tersendiri untuk memasuki, merebut, atau menciptakan pangsa pasarnya (Madhok dan Marques, 2014; Darroch, 2005). Selain itu, persaingan juga merupakan alasan bagi para pihak manajemen untuk berpegang pada prinsip keberlanjutan usaha (going concern) dalam menjalankan roda operasi perusahaan (Yovalia dan Wibowo, 2016).

Pengelolaan laba yang baik adalah merupakan salah satu usaha yang ditempuh oleh pihak manajemen dalam rangka mempertahankan keberlanjutan usaha (Silviu dan Timea, 2015; Perreault et al., 2017:45 ). Salah satu bentuk pengelolaan laba adalah perencanaan atas laba kontribusi dimana perusahaan dapat melakukan pengelolaan yang baik atas penjualan dan biaya-biayanya (Harris dan Mongiello, 2006:177; Yuan, 2009). Kajian ini bertujuan untuk memberikan pemahaman atas perencanaan laba kontribusi melalui metode estimasi biaya dan analisis kinerja laba melalui uji statistik khususnya bagi perusahaan manufaktur. Secara teknis akuntansi, perusahaan manufaktur merupakan jenis perusahaan yang memiliki kompleksitas usaha tersendiri dimana perusahaan tersebut melakukan produksi produk, menentukan harga jual produk, dan memasarkan produk tersebut.

Manajer membutuhkan informasi yang dihasilkan oleh sistem akuntansi biaya, ketika membuat keputusan, khususnya membandingkan biaya dan pendapatan dari berbagai alternatif yang tersedia. Manajer harus memperhitungkan konsekuensi keuangan dari alternatif-alternatif yang ada dengan melakukan estimasi bagaimana biaya, pendapatan dan asset berbeda atas alternatif-alternatif yang ada. Bagaimana mengetahui bahwa keputusan yang diambil mempengaruhi perusahaan? Hal ini memerlukan estimasi dan asumsi (Lanen, et al., 2014:10,161). Salah satu tahap penting dalam pengambilan keputusan jangka pendek adalah memisahkan biaya variabel dari biaya tetap. Pemisahan biaya ini bermanfaat untuk mengestimasi biaya yang dapat dikontrol dan untuk memaksimalkan laba kontribusi guna perencanaan dan pengendalian jangka pendek (Balakrishnan, et al., 2012:112). Aspek penting dalam pengambilan keputusan jangka pendek adalah pengambil keputusan tidak bisa 
merubah kapasitas, yaitu biaya tetap dan biaya yang tidak bisa dikontrol pada kurun waktu jangka pendek. Margin kontribusi adalah laporan yang fokus pada biaya variabel dan pendapatan yang merupakan komponen yang secara langsung mempengaruhi pengambilan keputusan jangka pendek (Balakrishnan, et al., 2012:117).

\section{TINJAUAN PUSTAKA}

Konsep laba kontribusi. Manajer harus memahami bagaimana perlakuan atas pendapatan dan biaya atau dalam arti bagaimana pengendalian agar tidak menghadapi risiko kerugian atau ketidakmpuan menciptakan laba (Horngren et al., 2015:24). Manajer seringkali dihadapkan pada situasi dimana manager harus mengambil keputusan yang paling menguntungkan bagi perusahaan. Bagaimana manajer dapat mengambil keputusan yang tepat, diawali dengan mengidentifikasikan mana yang termasuk biaya tetap dan biaya variabel, kemudian menghitung laba kontribusi. Biaya tetap adalah biaya yang tidak berubah berapapun jumlah unit yang terjual, sedangkan biaya variabel adalah biaya yang meningkat secara proporsional seiring meningkatnya jumlah unit yang dijual (Bhimani et al., 2019:34; Horngren et al., 2015:89). Pada saat menghitung laba operasional, maka jumlah yang berubah ketika unit yang dijual berubah adalah total pendapatan dan total biaya variabel. Perbedaan antara total pendapatan dan total biaya variabel adalah laba kontribusi dapat menggunakan Cost-Volume-Price Analysis (CVP) guna memahami perilaku dan hubungan antara total pendapatan, total biaya dan laba (Horngren et al., 2015:89).

Laba kontribusi $=$ Total pendapatan - Total biaya variabel

Metode pemisahan biaya. Analisis perilaku biaya merujuk pada usaha yang dilakukan untuk memahami bagaimana biaya-biaya operasional berubah ketika terjadi perubahan ukuran aktivitas perusahaan atau perubahan volume (Weygandt et al., 2012:952; Braun dan Tietz, 2015:327; Whitecotton et al., 2020:211). Manajer perlu memahami perilaku biaya dan mengidentifikasi biaya untuk membuat rencana laba jangka panjang. Berdasarkan perilaku, biaya dibagi atas biaya variabel, biaya tetap dan biaya gabungan (Hansen dan Mowen, 2007:72; Braun dan Tietz, 2015:88-89). Pengukuran dan identifikasi perilaku biaya memerlukan analisis dan pertimbangan. Hal yang penting dalam proses ini adalah melakukan klasifikasi apakah biaya termasuk dalam biaya variabel atau biaya tetap, selain itu dibutuhkan analisis atas biaya masa lalu. Menurut Wild et al. (2018:811) dan Whitecotton et al. (2020:216), terdapat 3 (tiga) metode yang digunakan dalam penentuan biaya variabel dan biaya tetap, yaitu: (1) scatter diagram; (2) high-low method; dan (3) regression.

Penentuan harga jual produk. Informasi variable cost dapat digunakan manajer untuk pengambilan keputusan internal (Wild et al., 2018:823). Guna memahami bagaimana perubahan biaya, manajer perlu mengidentifikasi biaya yang termasuk dalam biaya variabel dan biaya tetap (Hansen dan Mowen, 2007:422). Pendekatan laporan laba rugi menggunakan variable costing ditujukan untuk pengambilan keputusan internal, dilakukan dengan menghitung contribution margin yaitu pendapatan penjualan dikurangi biaya variabel. Contribution margin dikurangi biaya tetap adalah laba bersih operasi. Pendekatan laporan laba rugi ini tidak membedakan antara biaya manufaktur dengan biaya non-manufaktur (Whitecotton et al., 2020:227-228).

Metode cost-plus pricing berbasis variable costing. Terdapat dua metode perhitungan total biaya produk per unit yaitu: (1) variable costing, biaya produk meliputi biaya bahan baku, biaya tenaga kerja langsung dan biaya variabel overhead; dan (2) absorption costing, biaya produk meliputi biaya bahan baku, biaya tenaga kerja langsung dan biaya variabel dan biaya tetap overhead. Perbedaan dari kedua metode ini terletak pada biaya tetap overhead, dimana pada pendekatan variable costing, biaya tetap overhead tidak dimasukkan sebagai biaya produk, sedangkan pada absorption costing biaya tetap overhead dimasukkan sebagai biaya produk (Whitecotton et al., 2020:210; Wild, et al., 2018:850). 
Uji beda rata-rata. Uji beda rata-rata digunakan untuk membandingkan rata-rata dua sampel. Uji ini menggunakan langkah-langkah seperti pada pengujian hipotesis, yaitu menggunakan uji $z$ atau uji $t$. Hal yang perlu diperhatikan pada saat melakukan uji beda adalah menentukan apakah sampel merupakan independent sample atau dependent sample. Independent sample adalah dua kelompok rata-rata dari dua sampel yang tidak berhubungan, sedangkan dependent sample adalah sebuah kelompok sampel dengan subyek yang sama namun mengalami dua perlakuan atau pengukuran yang berbeda (Bluman, 2012:472-473, 484; Gravetter et al., 2018:268; Fry, 2014:430). Uji $z$ digunakan untuk menguji rata-rata dari suatu populasi, jumlah sampel $(n) \geq 30$, atau populasi terdistribusi normal dan standar deviasi populasi $(\sigma)$ diketahui (Bluman, 2012:413). Jika jumlah sampel $(n) \leq 30$, populasi terdistribusi normal dan standar deviasi populasi $(\sigma)$ tidak diketahui maka digunakan uji $t$ (Bluman, 2012:413, 485).

\section{METODE DAN TEKNIK PENERAPAN IPTEKS}

\subsection{Metode penerapan ipteks}

Metode penerapan ipteks dilakukan dengan metode deskriptif khususnya pemisahan biaya menggunakan metode regresi guna perencanaan laba. Setelah dilakukan pemisahan biaya, yaitu biaya variabel dan biaya tetap maka dilakukan uji beda untuk menguji apakah laba kontribusi antara tahun $\mathrm{t}$ dan tahun $\mathrm{t}_{1}$ berbeda signifikan.

\subsection{Teknik penerapan ipteks}

Teknis penerapatan ipteks adalah dengan melakukan identifikasi terhadap permasalahan pada perusahaan manufaktur, kemudian masalah tersebut dijelaskan secara teoritis. Setelah itu dilakukan penjelasan tentang cara mengatasi masalah dengan menggunakan pemisahan biaya menggunakan regresi guna merencanakan laba kontribusi.

\section{PEMBAHASAN}

\subsection{Gambaran objek penerapan ipteks}

Sektor ekonomi terdiri atas: (1) sektor manufaktur; (2) sektor perdagangan; dan (3) sektor jasa. Perusahaan manufaktur adalah perusahaan yang membeli bahan baku dan kemudian mengubahnya menjadai barang jadi (Horngren, et al., 2015:60). Menurut Lanen et al. (2011:44), operasi manufaktur merupakan kegiatan mengubah suatu barang dasar secara mekanis, kimia atau dengan tangan sehingga menjadi barang jadi atau setengah jadi. Sektor manufaktur merupakan salah satu sektor yang mendorong peningkatan ekonomi dan faktor produktif yang memaksimalkan pembangunan. Perkembangan sektor manufaktur diiringi meningkatnya kemajuan teknologi dan sumber daya manusia serta menjadi tujuan utama investor (Sholihah et al., 2017). Pada perusahaan manufaktur, biaya dikelompokkan berdasarkan perilaku biaya yaitu biaya variabel, biaya tetap, dan biaya campuran (Braun dan Tietz, 2015:328)

\subsection{Pembahasan}

Penerapan metode regresi guna perencanaan laba kontribusi dilakukan dengan: (1) memahami perilaku biaya; (2) pemisahan biaya; dan (3) penghitungan laba kontribusi. Konsep biaya merupakan hal penting dalam konteks perusahaan untuk pengambilan keputusan. Manajer perlu memahami perilaku biaya sehingga mendapatkan gambaran bagaimana perilaku atau perubahan total biaya ketika beberapa ukuran aktivitas berubah. Ukuran aktivitas antara lain adalah unit yang diproduksi atau jam tenaga kerja langsung (Whitecotton et al., 2020:211). Menurut Whitecotton et al. (2020:211-214), perilaku biaya dapat dikelompokkan menjadi: (1) biaya variabel; (2) biaya tetap; (3) biaya bertahap; dan (4) biaya campuran. Menurut Braun dan Tietz (2015:329-332), manajer dapat menggunakan persamaan biaya yang merupakan persamaan matematis yang dapat merepresentasikan bagaimana biaya berperilaku. Pada grafik biaya, garis vertikal merupakan (y-axis) yang 
menunjukkan total biaya, sedangkan garis horizontal ( $x$-axis) menunjukkan aktivitas volume.

Secara matematis persamaan biaya variabel adalah sebagai berikut:

Total biaya $(y)=$ Biaya variabel per unit aktivitas $(v)$ - Volume aktivitas $(x)$

atau,

$$
y=v x
$$

Persamaan matematis biaya tetap adalah sebagai berikut:

$$
\text { Total fixed cost }(y)=\text { Fixed amount over a period of time }(f)
$$

atau,

$$
y=v x
$$

Tahap selanjutnya agar dapat menentukan bagaimana total biaya akan berubah adalah manajer harus melakukan pemisahan biaya atas biaya variabel dan biaya tetap karena masingmasing biaya berperilaku berbeda. Pemisahan biaya-biaya sebagai biaya variabel dan biaya tetap merupakan dasar untuk melakukan analisis keputusan managerial (Whitecotton et al., 2020:215). Pemisahan biaya dapat dilakukan dengan high low method, scatterplot method, dan regression method (Wild, et al., 2018:811; Whitecotton et al., 2020:216). Kelemahan high-low method adalah kecenderungan melibatkan data tidak normal (outliers) dan hanya mempertimbangkan 2 (dua) titik utama yaitu titik tertinggi dan titik terendah yang merupakan dua titik yang ekstrim yang tidak merepresentasikan tren data secara keseluruhan (Budiarso, 2019). Berbeda dengan metode regresi yang menentukan titik secara matematis, menggunakan semua titik data dan perhitungannya sangat mudah (Whitecotton et al., 2020:223). Setelah melakukan analisa perilaku biaya dan pemisahan biaya maka tahap selanjutnya adalah membuat laporan laba kontribusi. Laporan laba kontribusi didasarkan pada perilaku biaya dan pemisahan biaya guna menentukan apakah biaya tersebut termasuk dalam klasifikasi biaya variabel atau biaya tetap. Laba kontribusi diperoleh dengan mengurangkan biaya variabel dari penjualan, setelah itu mengurangkan biaya tetap untuk mendapatkan laba bersih. Tabel 1 menyajikan data jumlah unit produk yang terjual dan total biaya per bulan dalam memproduksi produk.

Tabel 1. Data unit produksi dan total biaya produk pada tahun pertama

\begin{tabular}{lccccccc}
\hline \multicolumn{1}{c}{ Periode } & $\begin{array}{c}\text { Unit } \\
\text { produksi } \\
(\mathbf{X 2})\end{array}$ & $\begin{array}{c}\text { Total } \\
\text { biaya } \\
\text { (Y2) }\end{array}$ & $\begin{array}{c}\text { Biaya } \\
\text { tetap }\end{array}$ & $\begin{array}{c}\text { Biaya } \\
\text { variabel }\end{array}$ & $\begin{array}{c}\text { Harga } \\
\text { jual per } \\
\text { unit }\end{array}$ & Penjualan & $\begin{array}{c}\text { Laba } \\
\text { kontribusi }\end{array}$ \\
\hline Januari & 100 & 5,000 & 4,000 & 1,000 & 300 & 30,000 & 29,000 \\
Pebruari & 200 & 6,000 & 4,000 & 2,000 & 300 & 60,000 & 58,000 \\
Maret & 300 & 7,000 & 4,000 & 3,000 & 300 & 90,000 & 87,000 \\
April & 400 & 8,000 & 4,000 & 4,000 & 300 & 120,000 & 116,000 \\
Mei & 500 & 9,000 & 4,000 & 5,000 & 300 & 150,000 & 145,000 \\
Juni & 600 & 10,000 & 4,000 & 6,000 & 300 & 180,000 & 174,000 \\
Juli & 700 & 11,000 & 4,000 & 7,000 & 300 & 210,000 & 203,000 \\
Agustus & 800 & 12,000 & 4,000 & 8,000 & 300 & 240,000 & 232,000 \\
September & 900 & 13,000 & 4,000 & 9,000 & 300 & 270,000 & 261,000 \\
Oktober & 1,000 & 14,000 & 4,000 & 10,000 & 300 & 300,000 & 290,000 \\
November & 1,100 & 15,000 & 4,000 & 11,000 & 300 & 330,000 & 319,000 \\
Desember & 1,200 & 16,000 & 4,000 & 12,000 & 300 & 360,000 & 348,000 \\
\hline
\end{tabular}

Pada tahun pertama bulan Januari, diproduksi 100 unit dengan harga jual per unit Rp 300, biaya variabel Rp 1,000 dan baya tetap Rp 4,000 maka diperoleh laba kontribusi sebesar $\mathrm{Rp}$ 29,000. Setelah diidentifikasi perilaku biaya, maka dilakukan pemisahan biaya menggunakan metode regresi. Metode ini merupakan teknik statistik untuk mendapatkan garis linier yang fit yang meminimalisir error. Mengikuti proses analisis dari Whitecotton et al. (2020:222), Gambar 1 menunjukkan penerapan regresi least squares dengan menggunakan MS-Excel dengan cara memilih main menu data, data analysis, dan regression melalui penentuan Y range, $\mathrm{X}$ range, dan output range. 


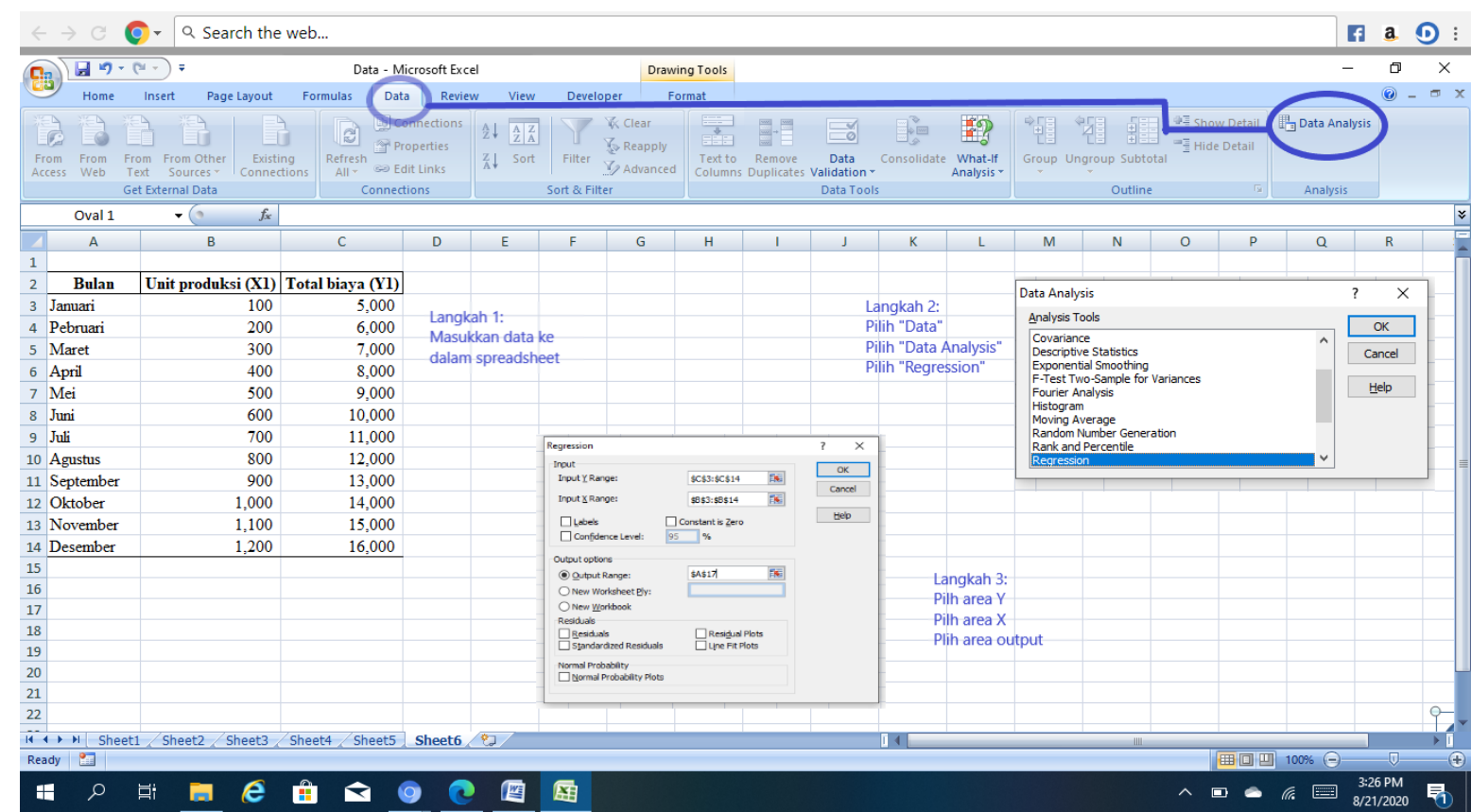

\section{Gambar 1. Penerapan metode regresi dengan menggunakan MS-Excel}

Hasil regresi menyajikan estimasi total biaya tetap (constant atau intercept) dan biaya variabel per unit (x coefficient atau slope). Tabel 2 menunjukkan total biaya tetap adalah $\mathrm{Rp}$ 4.000 dan estimasi biaya variabel adalah $\mathrm{Rp} 10$ per unit. Nilai $R$ square menunjukkan seberapa besar perubahan yang terjadi pada total biaya (y) yang dijelaskan oleh unit yang diproduksi (x). $R$ square sebesar 1 dari hasil regresi mengartikan bahwa 100 persen perubahan pada total biaya dijelaskan oleh unit yang diproduksi. Berdasarkan hasil regresi maka dapat dilakukan estimasi total biaya dengan menggunakan persamaan berikut.
Total biaya
Total biaya tetap + (Biaya variabel per unit $x$ aktivitas)
Total biaya
$=$
Rp 4,000 + (Rp $10 x$ unit yang diproduksi)

Tabel 2. Hasil regresi

\begin{tabular}{|c|c|c|c|c|c|c|c|c|}
\hline & Coefficients & $\begin{array}{c}\text { Standard } \\
\text { Error }\end{array}$ & t Stat & P-value & $\begin{array}{c}\text { Lower } \\
95 \%\end{array}$ & $\begin{array}{c}\text { Upper } \\
95 \%\end{array}$ & $\begin{array}{l}\text { Lower } \\
95.0 \% \\
\end{array}$ & $\begin{array}{l}\text { Upper } \\
95.0 \% \\
\end{array}$ \\
\hline Intercept & 4000 & $\begin{array}{l}3.42502 \mathrm{E}- \\
13\end{array}$ & $1.1679 \mathrm{E}+16$ & $\begin{array}{l}5.2135 \mathrm{E}- \\
157\end{array}$ & 4000 & 4000 & 4000 & 4000 \\
\hline X Variable 1 & 10 & $\begin{array}{l}4.65368 \mathrm{E}- \\
16\end{array}$ & $2.1488 \mathrm{E}+16$ & $\begin{array}{l}1.1724 \mathrm{E}- \\
159\end{array}$ & 10 & 10 & 10 & 10 \\
\hline
\end{tabular}

Hasil regresi di atas dapat digunakan untuk memprediksikan total biaya pada masa yang akan datang sepanjang jumlah unit produksi bisa diestimasi dalam area yang relevan. Sebagai contoh, jika perusahaan memprediksi unit yang diproduksi pada bulan Januari tahun kedua adalah 200, maka biaya tetap adalah $R p 4,000+(\operatorname{Rp} 10 \times 200$ unit) maka total biaya adalah Rp 4,200. Data prediksi jumlah unit yang diproduksi serta biaya tetap dan biaya variabel tahun kedua dapat dlihat pada Tabel 3. 


\begin{tabular}{lccccccc}
\hline \multicolumn{7}{c}{ Tabel 3. Data unit produksi dan total biaya produk tahun kedua (rencana 1) } \\
& $\begin{array}{c}\text { Unit } \\
\text { produksi } \\
\text { (X2) }\end{array}$ & $\begin{array}{c}\text { Total } \\
\text { biaya } \\
\text { (Y2) }\end{array}$ & $\begin{array}{c}\text { Biaya } \\
\text { tetap }\end{array}$ & $\begin{array}{c}\text { Biaya } \\
\text { variabel }\end{array}$ & $\begin{array}{c}\text { Harga } \\
\text { jual per } \\
\text { unit }\end{array}$ & Penjualan & $\begin{array}{c}\text { Laba } \\
\text { kontribusi }\end{array}$ \\
\hline Januari & 200 & 6,000 & 4,000 & 2,000 & 300 & 60,000 & 58,000 \\
Pebruari & 300 & 7,000 & 4,000 & 3,000 & 300 & 90,000 & 87,000 \\
Maret & 400 & 8,000 & 4,000 & 4,000 & 300 & 120,000 & 116,000 \\
April & 500 & 9,000 & 4,000 & 5,000 & 300 & 150,000 & 145,000 \\
Mei & 600 & 10,000 & 4,000 & 6,000 & 300 & 180,000 & 174,000 \\
Juni & 700 & 11,000 & 4,000 & 7,000 & 300 & 210,000 & 203,000 \\
Juli & 800 & 12,000 & 4,000 & 8,000 & 300 & 240,000 & 232,000 \\
Agustus & 900 & 13,000 & 4,000 & 9,000 & 300 & 270,000 & 261,000 \\
September & 1,000 & 14,000 & 4,000 & 10,000 & 300 & 300,000 & 290,000 \\
Oktober & 1,100 & 15,000 & 4,000 & 11,000 & 300 & 330,000 & 319,000 \\
November & 1,200 & 16,000 & 4,000 & 12,000 & 300 & 360,000 & 348,000 \\
Desember & 1,300 & 17,000 & 4,000 & 13,000 & 300 & 390,000 & 377,000 \\
\hline
\end{tabular}

Kenaikan produksi produk dari 100 unit pada bulan Januari tahun pertama menjadi 200 unit pada bulan Januari tahun kedua (rencana 1) dengan menggunakan persamaan regresi tahun pertama,dengan biaya tetap $\mathrm{Rp}$ 4,000 dan biaya variabel $\mathrm{Rp}$ 2,000 menghasilkan laba kontribusi sebesar Rp 58,000. Kenaikan produksi sebesar 100 unit meningkatkan laba kontribusi perusahaan sebesar 50\%. Tabel 4 menunjukkan penggunaan metode regresi untuk pemisahan biaya memberikan informasi kepada manajer bahwa pada tahun kedua, jika produksi ditingkatkan sebesar 100 unit maka total biaya akan meingkat juga sebesar Rp 1,000 dengan biaya tetap yang sama yaitu Rp 4,000 dan biaya variabel meningkat sebesar Rp 1,000.

Tabel 4. Data unit produksi dan total biaya produk tahun kedua (rencana 2)

\begin{tabular}{lccccccc}
\hline & $\begin{array}{c}\text { Unit } \\
\text { produksi } \\
\text { (X2) }\end{array}$ & $\begin{array}{c}\text { Total } \\
\text { biaya } \\
\text { (Y2) }\end{array}$ & $\begin{array}{c}\text { Biaya } \\
\text { tetap }\end{array}$ & $\begin{array}{c}\text { Biaya } \\
\text { variabel }\end{array}$ & $\begin{array}{c}\text { Harga } \\
\text { jual per } \\
\text { unit }\end{array}$ & Penjualan & $\begin{array}{c}\text { Laba } \\
\text { kontribusi }\end{array}$ \\
\hline Januari & 400 & 8,000 & 4,000 & 4,000 & 300 & 120,000 & 116,000 \\
Pebruari & 600 & 10,000 & 4,000 & 6,000 & 300 & 180,000 & 174,000 \\
Maret & 800 & 12,000 & 4,000 & 8,000 & 300 & 240,000 & 232,000 \\
April & 1,000 & 14,000 & 4,000 & 10,000 & 300 & 300,000 & 290,000 \\
Mei & 1,200 & 16,000 & 4,000 & 12,000 & 300 & 360,000 & 348,000 \\
Juni & 1,400 & 18,000 & 4,000 & 14,000 & 300 & 420,000 & 406,000 \\
Juli & 1,600 & 20,000 & 4,000 & 16,000 & 300 & 480,000 & 464,000 \\
Agustus & 1,800 & 22,000 & 4,000 & 18,000 & 300 & 540,000 & 522,000 \\
September & 2,000 & 24,000 & 4,000 & 20,000 & 300 & 600,000 & 580,000 \\
Oktober & 2,200 & 26,000 & 4,000 & 22,000 & 300 & 660,000 & 638,000 \\
November & 2,400 & 28,000 & 4,000 & 24,000 & 300 & 720,000 & 696,000 \\
Desember & 2,600 & 30,000 & 4,000 & 26,000 & 300 & 780,000 & 754,000 \\
\hline
\end{tabular}

Tabel 5 menunjukkan estimasi laba kontribusi melalui pendekatan variable costing berdasarkan rencana 1 dan rencana 2 yang mengacu pada data produksi tahun pertama.

Tabel 5. Laporan laba rugi laba kontribusi bulan Januari tahun pertama dan kedua

\begin{tabular}{lrrr}
\hline & $\begin{array}{c}\text { Tahun } \\
\text { pertama }\end{array}$ & $\begin{array}{c}\text { Tahun kedua } \\
\text { (rencana 1) }\end{array}$ & $\begin{array}{c}\text { Tahun kedua } \\
\text { (rencana 2) }\end{array}$ \\
\hline Penjualan (100 x Rp 300 (tahun 1), & 30,000 & 60,000 & 116,000 \\
200 x 300 (tahun 2 rencana 1), & & & \\
400 x 300 (tahun 2 rencana 1) & & & \\
(-) biaya variabel & 1,000 & 2,000 & 4,000 \\
Laba kontribusi & 29,000 & 58,000 & 112,000 \\
(-) biaya tetap & 4,000 & 4,000 & 4,000 \\
Laba bersih & 25,000 & 54,000 & 108,000 \\
\hline
\end{tabular}


Laba kontribusi merupakan estimasi laba rugi yang didasarkan pada perilaku biaya. Laba kontribusi merupakan hasil penjualan dikurangi biaya variabel yang memberikan informasi bagi manajer bagaimana pendapatan diperoleh dari penjualan sebelum memperhitungkan biaya tetap. Guna melihat apakah terdapat perbedaan signifikan antara rata-rata laba kontribusi (CM) tahun pertama dan rata-rata laba kontribusi tahun kedua (rencana 1) maka dilakukan independent t test, dengan hasil yang dapat dilihat pada Tabel 6. Hasil independent $t$ test antara laba kontribusi tahun pertama dengan laba kontribusi tahun kedua (rencana 1) menunjukkan bahwa nilai $\rho$ adalah $0.504>0.005$, artinya tidak terdapat perbedaan signifikan antara rata-rata laba kontribusi tahun pertama dengan rata-rata laba kontribusi tahun kedua (rencana 1). Besarnya perbedaan rata-rata atau mean kedua kelompok ditunjukkan pada kolom mean difference, yaitu 29000.0. Nilai rata-rata t hitung adalah 0.679 , nilai negatif menunjukkan bahwa rata-rata laba kontribusi tahun pertama memiliki rata-rata yang lebih rendah dari rata-rata laba kontribusi tahun kedua (rencana 1). Hasil ini menginformasikan bahwa meskipun terjadi peningkatan jumlah unit yang diproduksi dan peningkatan laba kontribusi, namun perbedaan ini tidak signifikan bagi perusahaan.

\begin{tabular}{|c|c|c|c|c|c|c|c|c|c|c|}
\hline & & \multicolumn{2}{|c|}{$\begin{array}{c}\text { Levene's Test for } \\
\text { Equality of } \\
\text { Variances } \\
\end{array}$} & \multicolumn{7}{|c|}{ t-test for Equality of Means } \\
\hline & & $\mathrm{F}$ & Sig & $\mathrm{t}$ & $\mathrm{df}$ & $\begin{array}{l}\text { Sig. (2- } \\
\text { tailed) }\end{array}$ & $\begin{array}{c}\text { Mean } \\
\text { Difference }\end{array}$ & $\begin{array}{l}\text { Std. Error } \\
\text { Difference }\end{array}$ & $\begin{array}{c}95 \% \\
\text { Confidence } \\
\text { Interval of the } \\
\text { Difference }\end{array}$ & $\begin{array}{c}95 \% \\
\text { Confidence } \\
\text { Interval of } \\
\text { the } \\
\text { Difference }\end{array}$ \\
\hline & & & & & & & & & Lower & Upper \\
\hline \multirow[t]{2}{*}{$\mathrm{CM}$} & $\begin{array}{l}\text { Equal } \\
\text { variances } \\
\text { assumed }\end{array}$ & 0.000 & 1.0 & -0.679 & 22 & 0.504 & 29000.0 & -29000.0 & -117527.10 & 59527.1 \\
\hline & $\begin{array}{l}\text { Equal } \\
\text { variances } \\
\text { not } \\
\text { assumed }\end{array}$ & & & -0.679 & 22.0 & 0.504 & 29000.0 & -29000.0 & -117527.10 & 59527.1 \\
\hline
\end{tabular}

Tabel 7 menunjukkan bahwa hasil independent $t$ test atas laba kontribusi (CM) pada tahun pertama dengan tahun kedua (rencana 2) menunjukkan bahwa nilai $\rho$ adalah $0.001<$ 0.005 , artinya terdapat perbedaan signifikan antara rata-rata laba kontribusi tahun pertama dengan rata-rata laba kontribusi tahun kedua (rencana 2). Besarnya perbedaan rata-rata atau mean kedua kelompok ditunjukkan pada kolom mean difference, yaitu 29000.0. Nilai ratarata t hitung adalah -3.652 , nilai negatif menunjukkan bahwa rata-rata laba kontribusi tahun pertama memiliki rata-rata yang lebih rendah dari rata-rata laba kontribusi tahun kedua (rencana 2). Hasil ini menginformasikan bahwa kenaikan jumlah unit yang diproduksi pada tahun kedua (rencana 2) menyebabkan perubahan terhadap rata-rata laba kontribusi dan perubahan laba kontribusi ini signifikan terhadap perusahaan.

Tabel 7. Hasil independent $t$ test laba kontribusi tahun pertama dan tahun kedua (rencana 2)

\begin{tabular}{|c|c|c|c|c|c|c|c|c|c|c|}
\hline & & \multicolumn{2}{|c|}{$\begin{array}{c}\text { Levene's Test for } \\
\text { Equality of } \\
\text { Variances }\end{array}$} & \multicolumn{7}{|c|}{ t-test for Equality of Means } \\
\hline & & $\mathrm{F}$ & Sig & $\mathrm{t}$ & $\mathrm{df}$ & $\begin{array}{l}\text { Sig. (2- } \\
\text { tailed) }\end{array}$ & $\begin{array}{c}\text { Mean } \\
\text { Difference }\end{array}$ & $\begin{array}{l}\text { Std. Error } \\
\text { Difference }\end{array}$ & $\begin{array}{c}95 \% \\
\text { Confidence } \\
\text { Interval of the } \\
\text { Difference }\end{array}$ & $\begin{array}{c}95 \% \\
\text { Confidence } \\
\text { Interval of } \\
\text { the } \\
\text { Difference }\end{array}$ \\
\hline & & & & & & & & & Lower & Upper \\
\hline \multirow[t]{2}{*}{$\mathrm{CM}$} & $\begin{array}{l}\text { Equal } \\
\text { variances } \\
\text { assumed }\end{array}$ & 6.789 & $\begin{array}{r}0.0 \\
16\end{array}$ & -3.652 & 22 & 0.001 & -246500.0 & 67493.83 & -386473.63 & -106526.4 \\
\hline & $\begin{array}{l}\text { Equal } \\
\text { variances } \\
\text { not } \\
\text { assumed }\end{array}$ & & & -3.652 & 16.176 & 0.002 & -246500.0 & 67493.83 & -389453.77 & -103546.2 \\
\hline
\end{tabular}




\section{KESIMPULAN DAN SARAN}

\subsection{Kesimpulan}

Analisis perilaku biaya dapat digunakan untuk memprediksi level biaya pada level aktivitas tertentu yang berfokus pada masa yang akan datang. Pemisahan biaya yang mengacu pada perilaku biaya dengan menggunakan metode regresi dapat diterapkan dengan mudah oleh manajer perusahaan manufaktur. Selain itu, secara statistik garis regresi dapat digunakan untuk menarik kesimpulan tentang hubungan antara biaya dan aktivitas. Metode ini merupakan metode estimasi biaya yang objektif sehingga dapat menjadi alat perencanaan laba jangka pendek dan menjadi kontrol biaya.

Agar informasi biaya menjadi lebih bermanfaat bagi manajer maka perlu dilakukan determinasi biaya atau pemisahan biaya, untuk mendeterminasikan biaya produk tergantung pendekatan yang digunakan. Pendekatan yang didasarkan pada perilaku biaya adalah laporan laba rugi laba kontribusi dimana hanya biaya variabel yang merupakan biaya produk. Pemisahan biaya yang digabungkan dengan metode variable costing dapat memberikan manfaat estimasi dan kontrol biaya dalam jangka pendek.

\subsection{Saran}

Metode pemisahan biaya menggunakan regresi memiliki keunggulan yaitu menggunakan semua data pada semua titik dan dapat menggunakan MS-Excel sehngga mudah untuk menghitung biaya produk, namun terdapat beberapa kelemahan yaitu membutuhkan banyak data dan asumsi dan perlu pemahaman statistik dalam mengnterpretasikan hasil regresi. Perlu dilakukan penyimpanan data secara berkala sehingga data yang diperlukan untuk perhitungan tersedia setiap saat dan perlu memaham teknik statistik guna menginterpretasikan hasil regresi.

\section{DAFTAR PUSTAKA}

Balakrishnan, R., Sivaramakrishnan, K., \& Sprinkle, G. B. (2012). Managerial accounting, Second Edition. United States of America: John Wiley \& Sons, Inc.

Bhimani, A., Horngren, C. T., Datar, S. M., \& Rajan, M. V. (2019). Management and cost accounting. Seventh Edition. United Kingdom: Pearson Education Limited.

Bluman, A. G. (2012). Elementary statistics: A step by step approach, Eighth Edition. New York: McGraw-Hill.

Braun, K., \& Tietz, W. M. (2015). Managerial accounting, Fourth Edition. England: Pearson Education Limited.

Budiarso, N. S. (2019). Ipteks estimasi biaya bagi usaha kecil menengah dalam perencanaan biaya. Jurnal Ipteks Akuntansi bagi Masyarakat, 3(1), 2934. https://doi.org/10.32400/jiam.3.1.2019.23306

Darroch, J. (2005). Knowledge management, innovation and firm performance. Journal of Knowledge Management, 9(3), 101-115. https://doi.org/10.1108/13673270510602809

Fry, G. S. (2014). Business statistics a decision-making approach, Ninth Edition. United Kingdom: Pearson Education Limited.

Gravetter, F. J., Wallnau, L. B., \& Forzano, L. A. B. (2018). Essentials of statistics for the behavioral sciences, Ninth Edition. United States of America: Cengage Learning.

Hansen, D. R., \& Mowen, M. M. (2007). Managerial accounting, $8^{\text {th }}$ Edition. United States of America: Thomson South-Western.

Harris, P., \& Mongiello, M. (2006). Accounting and financial management developments in the international hospitality industry. Burlington: Elsevier Ltd.

Horngren, C. T., Datar, S. M. \& Rajan, M. V. (2015). Cost accounting: A managerial emphasis, Fifteenth Edition. England: Pearson Education Limited. 
Jensen, M. C., \& Meckling, W. H. (1976). Theory of the firm: Managerial behavior, agency costs and ownership structure. Journal of Financial Economics, 3(4), 305-360. https://doi.org/10.1016/0304-405X(76)90026-X

Lanen, W. N., Anderson, S. W., \& Maher, M. W. (2014). Fundamentals of cost accounting, Fourth Edition. United States of America: McGraw-Hill/Irwin

Lorenzon, J. R. F., Rubio, M. T. M., \& Garcés, S. A. (2018). The competitive advantage in business, capabilities and strategy. What general performance factors are found in the Spanish wine industry? Wine Economics and Policy, 7, 94-108. https://doi.org/10.1016/j.wep.2018.04.001

Madhok, A. \& Marques, R. (2014). Towards an action-based perspective on firm competitiveness. BRQ Business Research Quarterly, 17(2), 77-81. https://doi.org/10.1016/j.brq.2014.03.002

Ozuomba, C. N., Anichebe, A. S., \& Okoye, P. V. C. (2016). The effect of dividend policies on wealth maximization-a study of some selected plcs. Cogent Business and Management, 3(1), 1-15. https://doi.org/10.1080/23311975.2016.1226457

Perreault, W. D., Cannon, J. P., \& McCarthy, E. J. (2017). Essentials of marketing: A marketing strategy planning approach, $15^{\text {th }}$ Edition. New York: McGraw-Hill Education

Ross, S. A., Westerfield, R. W., \& Jordan, B. D. (2017). Essentials of corporate finance, Ninth Edition. New York: McGraw-Hill.

Sholihah, I. M., Syaparuddin, \& Nurhayani. (2017). Analisis investasi sektor industri manufaktur, pengaruhnya terhadap pertumbuhan ekonomi dan penyerapan tenaga kerja di Indonesia. Jurnal Paradigma Ekonomika, 12(1), 11-24. https://onlinejournal.unja.ac.id/paradigma/article/view/3930

Silviu, C. G., \& Timea, F. M. (2015). New audit reporting challenges auditing the going concern basis of accounting. Procedia Economics and Finance, 32, 216-224. https://doi.org/10.1016/S2212-5671(15)01385-4

Weerawardena, J., \& O'Cass, A. (2004). Exploring the characteristics of the market-driven firms and antecedents to sustained competitive advantage. Industrial Marketing Management, 33(5), 419-428. https://doi.org/10.1016/j.indmarman.2003.07.002

Weygandt, J. J., Kimmel, P. D., \& Kieso, D. E. (2012). Managerial accounting tools for business decision making, Eighth Edition. United States: John Wiley \& Sons.

Whitecotton, S., Libby, R. \& Phillips, F. (2020). Managerial accounting, Fourth Edition. Unites States of America: McGraw-Hill Education

Wild, J. J., Shaw, K. W., \& Chiappetta, B. (2018). Financial and managerial accounting: Information for decisions, $7^{\text {th }}$ Edition. New York: McGraw-Hill Education,

Yovalia, S., \& Wibowo, W. (2016). Pengaruh business strategy dan business risk terhadap going concern pada perusahaan manufaktur yang terdaftar di BEI tahun 2010-2014. Jurnal Akuntansi Trisakti, 3(2), 177-192. http://dx.doi.org/10.25105/jat.v3i2.4962

Yuan, F. C. (2009). The use of a fuzzy logic-based system in cost-volume-profit analysis under uncertainty. Expert Systems with Applications, 36, 1155-1163. https://doi.org/10.1016/j.eswa.2007.11.025 